\title{
Komparasi Pemikiran Yunani dan Yesus Kristus tentang Perempuan
}

\author{
The Comparasion of Greek's and Jesus Christ's thought on Woman
}

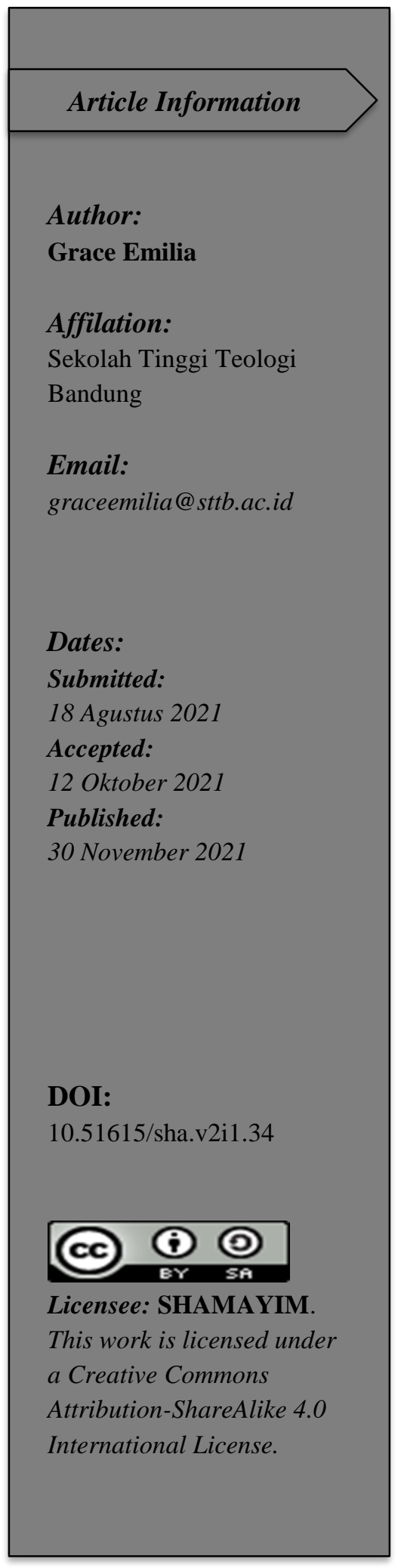

Abstract: This article explores the views on woman by comparing Greek-rooted thoughts prevailed upon the the Greek, Romans, and Jewish antiquities with Jesus Christ's perspective, especially those written in the Synoptic Gospel and the Gospel of John. This study uses the multimethod research to gain a more thorough understanding about the issue. The integrative literature review is used to get insight on Greek philosophy's perspective on woman and its influences on the thoughts existed in the Romans and Jewish antiquities. Meanwhile, the narrative-analysis method is used to gain understanding about Jesus Christ's perspective on woman. This study concludes that the Son of God opposes various Greek-rooted thoughts on woman and shows that woman is God's worthy creature and the heir of His promises for humanity.

Keywords: Women, Greek Philosophy, Greek-Romans-Jewish Antiquities, Jesus Christ, Gospel

Abstrak: Tulisan ini menelaah pandangan tentang perempuan melalui komparasi antara perspektif yang berakar dari pemikiran Yunani yang terdapat di tengah masyarakat Yunani, Romawi dan Yahudi kuno dengan pandangan Yesus Kristus tentang perempuan yang terdapat di Injil Sinoptik dan kitab Yohanes. Digunakan cara penelitian multi-metode dalam kajian ini untuk mendapatkan pemahaman yang lebih menyeluruh tentang isu ini. Metode studi pustaka dengan pendekatan integratif digunakan untuk menelaah perspektif terhadap perempuan dalam pemikiran Yunani kuno dan pengaruhnya pada pemikiran Romawi dan Yahudi kuno. Sementara itu, metode analisis naratif digunakan untuk melihat pandangan Yesus Kristus tentang perempuan yang terdapat di Injil Sinoptik dan kitab Yohanes. Dari penelaahan ini disimpulkan bahwa Sang Anak Allah menentang berbagai pemikiran yang berakar dari filsafat Yunani dan justru menunjukan bahwa perempuan adalah ciptaan Allah yang berharga dan merupakan pewaris janji-janji-Nya bagi umat manusia.

Kata Kunci: Perempuan, Pemikiran Yunani, Yunani-Romawi-Yahudi Kuno, Yesus Kristus, Injil 


\section{Pendahuluan}

Peradaban Yunani kuno mulai muncul di sekitar tahun 1600 - 1200 SM dengan puncak keemasannya di sekitar tahun 400 SM ketika Makedonia diperintah oleh Raja Philip. Anaknya, Alexander Agung, memperluas kerajaan ayahnya menjadi kekaisaran yang terbentang luas sampai ke India. Sejak saat itu budaya Yunani menyebar ke berbagai penjuru dunia kuno (Sacks, 2005).

Pada periode yang kerap dirujuk sebagai periode klasik ini, yaitu di sekitar abad ke-5 dan ke-4 Sebelum Masehi (SM), filsafat Yunani berkembang pesat. Para filsuf, pujangga dan sejarawan Yunani klasik bermunculan, khususnya di kota Athena. Nama-nama besar dalam sejarah budaya dan intelektual di Eropa Barat hidup di Athena pada periode ini: Aesiklus, Aristopanes, Euripides, Sopokles, filsuf Sokrates, Plato dan Aristoteles, sejarawan Herodotus, Thusidides, dan Xenophonus, pujangga Simonidus, serta pematung Phidias (Seitkasimova, 2019).

Pemikiran dari para tokoh di periode ini berpengaruh besar pada peradaban Barat modern, termasuk di area seni, arsitektur, literatur, filsafat, dan ilmu pengetahuan, termasuk pada kekristenan (Sacks, 2005). Salah satu filsuf Yunani klasik yang namanya paling banyak tercatat di berbagai teks para pemikir Kristen dari jaman kekristenan awal adalah Plato. Itulah sebabnya Platonisme mendominasi pemikiran dari para bapa gereja (Edwards, 2010). Salah satu contoh aplikasinya ditunjukkan oleh sejarawan Susanna Elm dalam bukunya "Sons of Hellenism: Fathers of the Church". Di karyanya itu Elm menunjukkan bahwa akar dari model kepemimpinan Kristen Romawi bukan berakar dari Perjanjian Baru dan budaya Yahudi, tapi dari pemikiran kaum elit yang sangat dipengaruhi oleh pemikiran Plato dan Aristoteles (Elm, 2012).

Namun ironisnya, bagi perempuan Yunani, periode klasik ini justru merupakan periode yang paling suram karena di periode inilah pandangan yang sangat negatif terhadap perempuan menjadi semakin mengkristal. Para tokoh besar, khususnya para filsuf, umumnya melihat perempuan sebagai gender yang lebih rendah dari laki-laki. Dalam karyanya yang berjudul Timaeus, Plato membandingkan laki-laki pengecut dan yang hidupnya tidak benar dengan perempuan. Sementara dalam maha karyanya Republic, Plato terus-menerus menyatakan superioritas laki-laki dibanding perempuan. Ia juga merendahkan perempuan sebagai bonus pemuas seksual bagi mereka yang berani maju ke medan perang, dan ia menertawakan ide tentang perempuan mendapatkan pendidikan yang sama dengan laki-laki (Aghababian, 2015).

Aristoteles adalah murid Plato yang paling berpengaruh. Ia kerap berbeda pandangan dengan Plato. Namun dalam konteks pandangan terhadap perempuan, mereka memiliki banyak kemiripan. Dalam karya besarnya Politics, tutor dari Alexander Agung ini menyatakan bahwa ada ketidak-sederajadan permanen antara laki-laki dan perempuan (Stagg, 1978). Menurut Aristoteles, perempuan sama seperti budak, dimana tugas keduanya adalah sebagai 'pekerja'; dan pekerjaan utama perempuan adalah menghasilkan anak. Itulah sebabnya perempuan perlu diatur demi kebaikan bersama dari komunitas (Aghababian, 2015). Aristoteles bahkan menyatakan bahwa kebebasan yang terlalu besar bagi perempuan adalah suatu kejahatan politis (Swidler, 1976). Pernyataan Aristoteles ini tampaknya menegaskan pandangan Plato dalam Republic mengenai pentingnya pembagian masyarakat berdasarkan gender dimana perempuan perlu diisolasi dari kehidupan publik (Aghababian, 2015).

Pandangan para filsuf Yunani ini terus berpengaruh dari budaya ke budaya dan dari jaman ke jaman, termasuk kepada bapa gereja. Salah seorang bapa gereja yang kerap disebut sebagai bapa dari kekristenan Barat, yaitu Tertullianus $(155-220 \mathrm{M})$ turut terpengaruh. Ia menyatakan bahwa perempuan adalah pintu gerbang setan karena telah membuka meterai dosa dan telah membujuk Adam yang tidak bisa diserang oleh 
iblis. Ia juga menyatakan bahwa perempuan telah menghancurkan gambar Allah, yaitu laki-laki. Akibat dari dosa perempuan adalah kematian, bahkan Anak Allah pun harus mati (Pape, 1976).

Sebelum masa Konstantin Agung (yang menjadikan kekristenan sebagai agama resmi negara), perempuan berperan aktif di berbagai urusan gerejawi. Mereka bertugas sebagai nabiah, rasul, martir, guru, presbiter, dan beberapa sebagai bishop. Pengangkatan sebagai bishop itu sesuatu yang mungkin karena perempuan-perempuan berpengaruh seperti Priskila, Lidia, Nimpa dan Tavia tercatat sebagai para pemimpin gereja rumah. Namun di abad ke-3 M, beberapa teolog Kristen seperti Tertulianus mengajarkan bahwa perempuan berdosa dan lebih rendah dari laki-laki, karena itu perempuan tidak boleh mengajar. Pandangan ini semakin menguat ketika kekristenan resmi menjadi agama negara di abad ke-4 M dimana gereja menjadi semakin tersentralisasi dan melekat dengan kekaisaran Romawi (Nicolaides, 2016).

Berdasarkan situasi ini, penulis hendak menelaah perspektif terhadap perempuan dari berbagai literatur Yunani kuno serta warisan pengaruhnya dalam pemikiran Romawi kuno, dan Yahudi kuno. Setelah itu penulis hendak mengobservasi pandangan dan sikap Yesus Kristus terhadap perempuan dari beberapa interaksi-Nya dengan perempuan yang terdapat di Injil Sinoptik dan di kitab Yohanes. Ketika Yesus Kristus berinkarnasi sebagai manusia, Ia hidup di tengah latar-belakang berbagai pemikiran dan budaya tersebut. Berdasarkan eksplorasi ini, penulis berharap bisa mendapatkan kejelasan pandangan mengenai perempuan setelah melihat komparasi antara perspektif yang berakar dari filsafat Yunani dengan perspektif Alkitabiah, khususnya yang terdapat di Injil Sinoptik dan Injil Yohanes.

\section{Metode Penelitian}

Tulisan ini menggunakan cara penelitian multi-metode (multimethod research) yang didefinisikan sebagai praktik menggunakan dua atau lebih metode atau gaya penelitian di dalam suatu penelitian, dan tidak membatasi penelitian pada penggunaan satu metode saja (Hunter \& Brewer, 2015).

Metode studi pustaka dengan pendekatan integratif digunakan untuk menelaah perspektif terhadap perempuan dalam pemikiran Yunani kuno dan pengaruhnya pada pemikiran di budaya Romawi dan Yahudi kuno. Dengan menggunakan metode ini, penulis mengumpulkan berbagai informasi yang relevan dari sumber-sumber literatur sekunder (termasuk buku, jurnal dan ensiklopedia) yang membahas isi dari literatur-literatur primer yang ditulis oleh para pemikir dari Yunani, Romawi dan Yahudi kuno serta oleh bapa-bapa gereja. Sementara itu pendekatan integratif digunakan untuk menilai, mengkritisi, serta mensintesa berbagai jenis literatur dari topik yang diteliti sehingga dapat memunculkan perspektif baru (Snyder, 2019).

Metode analisis naratif digunakan untuk melihat pandangan Yesus tentang perempuan. Metode ini melihat isi dari berbagai bagian narasi sebagai sekumpulan peristiwa, pengalaman, atau tindakan dengan alur cerita yang saling terkait dan membentuk suatu makna yang utuh. Melalui proses ini, penulis memberikan interpretasi atau komentar evaluatif mengenai topik yang diangkat (Feldman et al., 2004). Berbagai bagian narasi yang ditelaah di tulisan ini merupakan beberapa contoh interaksi Yesus Kristus dengan perempuan yang terdapat di Injil Sinoptik dan di kitab Yohanes. Dari proses interaksi ini bisa terlihat latar belakang budaya yang dihidupi pada masa tersebut.

Melalui penggunaan multi-metode ini diharapkan bisa ada kejelasan pandangan mengenai perempuan yang didapatkan dari perbandingan antara persektif yang berakar dari pemikiranYunani dengan perspektif Alkitabiah, khususnya yang terdapat di Injil Sinoptik dan Injil Yohanes. 


\section{Hasil dan Pembahasan}

\section{Pandangan terhadap Perempuan dalam Perspektif Yunani Kuno}

Pandangan negatif masyarakat Yunani kuno terhadap perempuan sebetulnya sudah muncul jauh sebelum era Plato dan Aristoteles di abad ke-4 dan ke-3 SM. Pujangga Hesiod yang hidup di sekitar tahun 750 - 650 SM misalnya, menggambarkan perempuan sebagai sumber segala duka. Dalam karyanya Works and Days, Hesiod memunculkan seorang tokoh perempuan bernama Pandora yang dianggap sebagai sumber segala masalah dan kesusahan. Baginya, Pandora adalah representasi dari perempuan pada umumnya.

Hesiod meyakini bahwa pada dasarnya laki-laki hidup di dunia tanpa masalah, rasa sakit atau penyakit, sampai Pandora membuka kotak yang ia bawa ke dalam kehidupan manusia dan mengeluarkan berbagai bencana dari dalamnya. Sejak saat itu Pandora telah mengambil seluruh kehidupan, rasa aman, dan kesejahteraan umat manusia dan menggantinya dengan masalah demi masalah (Too, 2001). Pandangan Hesiod ini diikuti oleh Sophocles (497 - 406 SM), salah satu penulis drama terbesar di periode Yunani klasik. Sophocles menyatakan bahwa "berdiam diri adalah kemuliaan perempuan" (Nicolaides, 2016), yang kemudian dikutip oleh Aristoteles dalam karyanya Politics.

Sementara itu melalui maha karyanya Iliad, pujangga Homer $( \pm 750 \mathrm{SM})$ mendeskripsikan perempuan sebagai properti. Di situ perempuan digambarkan bukan sebagai pelaku ekonomi yang melakukan pertukaran, tapi sebagai objek pertukaran: yaitu sebagai hadiah yang dapat diperjual-belikan di antara laki-laki, hadiah untuk dimenangkan di dalam peperangan atau pertandingan atletik, serta anak perempuan untuk diberikan di dalam pernikahan (Lyons, 2003). Itulah sebabnya secara legal, perempuan adalah properti milik ayah dan lalu suami. Jika menjanda atau menjadi yatim sebelum menikah, perempuan akan dipercayakan kepada kerabat pria terdekat yang juga akan mewarisi kekayaan yang ditinggalkan. Dianggap tidak bijaksana jika perempuan (yang adalah properti) memiliki properti sendiri (Frost, 1971).

Dengan demikian, pernikahan dapat menjadi sarana bagi laki-laki untuk mendapatkan harta, karena ketika menikahkan anak perempuannya, seorang ayah harus menyediakan mas kawin dalam bentuk uang, pakaian, perhiasan, dan bahkan budak. Tanpa mas kawin, sangat kecil kemungkinannya untuk seorang perempuan dapat menikah (Durant, 1939). Walau kadang, seperti yang dinyatakan dalam Iliad, seorang perempuan bisa menjadi objek hadiah yang berharga untuk mempererat hubungan di antara dua keluarga. Itulah sebabnya, perempuan disebutkan sebagai "diberikan di dalam pernikahan". Pemberian hadiah ini tidak setara, sebab ketika perempuan diberikan sebagai hadiah bagi suaminya, sang suami tidak dianggap sebagai hadiah bagi istrinya (Lyons, 2003).

Tujuan dan fungsi utama perempuan adalah untuk melahirkan anak-anak dan untuk menjadi penjaga setia dari properti di rumah, seperti yang dinyatakan dalam orasi Against Neaira dalam kumpulan tulisan Demosthenes. Hal serupa dinyatakan dalam orasi Lysias yang berjudul On the Murder of Eratosthenes. Tokoh dalam orasi tersebut yang bernama Euphiletos mengatakan bahwa di awal pernikahannya dengan istrinya, ia mengawasi istrinya dengan ketat. Tetapi ketika sang istri sudah melahirkan anak laki-laki baginya, maka ia mulai memberinya kepercayaan untuk bisa mengatur urusan rumah tangganya (Lyons, 2003).

Xenophonus (430 - 354 SM), sejarawan dari Athena, menjelaskan tentang isu perempuan dari perspektif kekuatan fisik dan keberanian. Di dalam karyanya Oeconomicus yang berisi pengajaran bagi istri, Xenophanus menjelaskan bahwa laki-laki lebih memiliki kekuatan fisik dan keberanian untuk bertahan dalam kondisi sulit. Sementara perempuan memiliki natur yang lebih rapuh karena lebih mudah 
merasa takut. Karena itu perempuan diberi tanggung-jawab untuk hal-hal di dalam rumah, sementara lakilaki di luar rumah (Oost, 1978).

Perkembangan ekonomi kota Athena turut berkontribusi pada munculnya berbagai pandangan yang di masa kini dilihat sebagai diskriminatif terhadap perempuan. Sejarawan Leipoldt menjelaskan bahwa Athena menjadi kota yang kaya karena bisnis ekspor dan perdagangannya berkembang pesat. Sebagai dampaknya, banyak laki-laki yang tidak perlu bekerja. Kaum perempuan pun tidak punya alasan lagi untuk bekerja di luar rumah. Namun situasi ini menyebabkan laki-laki berpikir bahwa perempuan adalah properti pribadi yang indah tapi tidak berguna dan dapat dipertahankan dengan menyimpannya rapat-rapat di rumah (Swidler, 1976).

Di area publik, profesi yang mungkin dilakukan oleh perempuan adalah sebagai hetaira atau perempuan yang dibayar untuk menemani dan memberikan jasa seksual. Hal ini diketahui antara lain dari tulisan Aristophanes (446 - 386 SM), pujangga dari Athena yang menulis tentang keberadaan hetaira di beberapa karyanya, antara lain Pax 439-440 dan Thesm. Hetaira ini kadang hadir dalam simposium (pesta yang hanya dihadiri kaum laki-laki) untuk menemani mereka yang hadir di acara itu. Beberapa hetaira, khususnya yang sangat cantik dan sudah mendapatkan pelatihan khusus, terkenal sebagai para perempuan kaya dan berkuasa (Glazebrook, 2020).

Hetaira ini adalah satu-satunya kalangan perempuan terdidik dengan siapa seorang laki-laki dapat mendiskusikan berbagai peristiwa yang terjadi, karya-karya sastra, teater, politik, dan filsafat (Frost, 1971). Negarawan dan orator ulung Demosthenes (484 - 322 SM) menyatakan bahwa laki-laki memiliki hetaira untuk kesenangan (hedone), dayang-dayang untuk memenuhi kebutuhan jasmani sehari-hari (therapeia), dan istri untuk memiliki anak-anak yang sah selain juga sebagai pengurus rumah yang setia (Swidler, 1976).

Kilasan berbagai pemikiran yang mendominasi masyarakat Yunani kuno ini menunjukan adanya pandangan yang cenderung negatif terhadap perempuan dan cenderung melihat perempuan sebagai properti atau harta milik yang perlu diawasi, dikendalikan dan dijaga karena secara natur perempuan dianggap bersifat destruktif.

\section{Pengaruh Perspektif Yunani terhadap Perempuan dalam Masyarakat Romawi}

Ketika bangsa Romawi menguasai Yunani, mereka mengimpor budaya Yunani sebagai bagian dari budaya Romawi. Mereka bahkan mengikuti agama orang Yunani dengan menggunakan dewa-dewi Yunani untuk menjadi dewa-dewi Romawi. Selain itu mereka pun mengkopi koin mata uang, arsitektur, seni, dan literatur Yunani. Itulah sebabnya di masa kini, kita secara otomatis menyebut warisan budaya Romawi sebagai 'Greco-Roman' yang menjadi warisan permanen di Eropa dan Mediteranian Timur (Sacks, 2005). Dengan demikian, tidaklah mengherangkan jika terdapat kemiripan pandangan mengenai perempuan di berbagai literatur Romawi kuno dengan di literatur Yunani kuno.

Salah satu warisan perspektif Yunani dalam kehidupan keluarga masyarakat Romawi dalam kaitannya dengan perempuan adalah kecenderungan untuk melihat perempuan sebagai 'mesin' penghasil anak. Keberhargaan perempuan dilihat dari kemampuannya menghasilkan keturunan. Namun ketika jumlah atau gender anak yang dihasilkan melebihi kapasitas ekonomi, maka laki-laki (dalam hal ini ayah / suami) berhak untuk menentukan hidup atau matinya.

Filsuf Yunani Aristoteles menyatakan dalam Politeia bahwa pembunuhan bayi perempuan dapat menjadi solusi untuk membatasi jumlah keluarga dan populasi di Athena (Haentjens, 2000). Ide Aristoteles ini bergaung kembali dalam tulisan Dionysius dari Halicarnassus (60 SM - $7 \mathrm{M}$ ) yang menulis dalam 
Antiquities of Rome mengenai "Konstitusi Romulus". Di situ ia menyatakan bahwa warga negara harus membesarkan semua anak laki-laki (kecuali anak laki-laki cacat yang diakui kecacatannya oleh lima orang tetangganya) dan anak perempuan pertama (Clark, 1981). Ini berarti jika sebuah keluarga memiliki lebih dari satu anak perempuan, maka ayah berhak untuk tidak membesarkannya atau bahkan untuk tidak membiarkannya hidup.

Ahli hukum Romawi yang bernama Gaius (130-180 M) menulis dalam Institutes mengenai kuatnya penerapan tradisi Patria Potestas di tengah sistem kekeluargaan masyarakat Romawi. Di dalam tradisi ini, ayah berkuasa penuh atas kehidupan keluarganya; dimana salah satunya adalah tentang penentuan hidup bayi. Jika ayah memutuskan bahwa bayinya itu akan dibunuh, maka tidak ada hukum yang melarang hal itu. Bayi perempuan biasanya memiliki kesempatan yang lebih kecil untuk bisa hidup dibandingkan bayi laki-laki (Clark, 1981).

Kondisi ekonomi biasanya menjadi alasan utama dilakukannya pembunuhan bayi. Plutarch (46 - 119 M) menulis dalam Moralia bahwa pembunuhan bayi umumnya dilakukan oleh kalangan rakyat miskin karena mereka tidak dapat memberi makan semua anak. Selain itu, keluarga pun harus membayarkan mas kawin (anak perempuan) jika mereka menikah sehingga menyulitkan ekonomi keluarga jika ada terlalu banyak anak perempuan. Pembunuhan bayi laki-laki terjadi jika sebuah keluarga sudah mempunyai terlalu banyak anak laki-laki sehingga berpotensi harus membagi warisan ke terlalu banyak anak (Haentjens, 2000).

Di sisi lain, melahirkan anak merupakan hal yang sangat penting bagi perempuan di Yunani maupun Romawi kuno karena hal inilah yang menjadikannya berharga. Walaupun perempuan Romawi bisa mendapatkan proteksi legal dan kebebasan yang lebih dibandingkan perempuan di Yunani kuno; tetapi hak itu baru diberikan setelah ia melahirkan anak-anak (Mosier-Dubinsky, 2013). Jika seorang perempuan dapat melahirkan minimal tiga orang anak, maka ia akan dihormati sebagai ibu dan istri yang berharga dalam masyarakat. Tetapi jika mandul, maka ia terancam untuk menjadi kaum yang terbuang (Dupont, 1989).

Namun melahirkan anak bukanlah hal yang mudah karena banyak yang mati dalam prosesnya, baik karena infeksi, proses kelahiran yang sulit, atau karena mereka berusia terlalu muda. Informasi ini dicatat oleh Soranus dari Efesus, dokter Romawi dari abad ke-2 M yang menulis sekitar dua puluh buku di area kedokteran. Namun karyanya yang utama, Gynaecology, menjadikannya sebagai dokter kandungan paling terkenal di Romawi kuno (Karamanous et al., 2013).

Ia meyakini bahwa usia 15 tahun merupakan usia yang tepat untuk bisa terjadinya pembuahan. Tentu saja ginekolog masa kini akan menyatakan bahwa seorang perempuan perlu setidaknya berusia 18 tahun untuk menikah (Clark, 1981). Sebagai akibatnya, banyak perempuan muda Romawi yang berusia antara 16 hingga 35 tahun meninggal karena harus terus-menerus melahirkan anak. Jumlah perempuan yang meninggal akibat melahirkan jumlahnya bisa jauh lebih besar dibandingkan laki-laki yang meninggal di medan perang (Dupont, 1989). Jumlah bayi yang meninggal pun cenderung tinggi. Cornelia, ibu dari Tiberus Gracchus, misalnya, melahirkan 12 orang anak, tapi hanya 3 anak yang bertahan hidup hingga dewasa (Todman, 2007).

\section{Pengaruh Perspektif Yunani terhadap Perempuan dalam Masyarakat Yahudi Kuno}

Meskipun secara religi orang Yahudi tidak banyak dipengaruhi oleh politeisme Yunani-Romawi, namun di dalam keseharian, mereka (khususnya kaum Yahudi diaspora yang tinggal di luar Palestina) menghidupi budaya Yunani. Mereka datang ke berbagai teater orang Yunani, berolah-raga di gimnasium Yunani, dan menggunakan bahasa Yunani untuk perdagangan dan kehidupan publik lainnya. Bahkan di 
daerah Alexandria di Mesir, orang-orang Yahudi yang berbahasa Yunani sudah tidak bisa lagi menggunakan bahasa Ibrani dan bahasa Aram. Itulah sebabnya, terjemahan bahasa Yunani dari Alkitab bahasa Ibrani mulai diproduksi di Alexandria sekitar 200 M. Dengan kata lain, budaya Yudaisme dihidupi di dalam wujud Yunani. Bahkan, rumah ibadah orang Yahudi pun disebut sebagai sinagoge yang berasal dari bahasa Yunani sunagoge yang berarti 'tempat berkumpul' (Sacks, 2005).

Pengaruh pemikiran Yunani juga mewujud di dalam pandangan tentang perempuan. Kitab Ben Sira yang ditulis di sekitar tahun 200 - 175 M oleh seorang Saduki yang bernama Ben Sira dari Yerusalem, misalnya, diyakini telah dipengaruhi oleh pemikiran Yunani, khususnya dalam perspektifnya mengenai perempuan. Ide-idenya yang berakar dari filsafat Yunani terindikasi di dalam struktur maupun isi tulisannya (Cook, 2008).

Kitab Ben Sira dengan tegas melarang perempuan Yahudi mempelajari Torah dan melihat anak-anak perempuan sebagai beban yang menyulitkan, karena mereka hanya merupakan makhluk seksual (Swidler, 1976). Ben Sira yang cenderung berlandaskan pada budaya honor-and-shame melihat bahwa seksualitas merupakan kehormatan bagi laki-laki, tapi bersifat memalukan bagi perempuan. Karena itulah laki-laki harus mengontrol perempuan supaya kehormatannya bisa terwujud. Selain itu, Ben Sira juga menyatakan bahwa istri yang baik sama dengan properti yang baik, karena itu kitab ini membandingkan istri yang baik dengan ternak sapi atau kebun anggrek (Coggins, 1998). Ide tentang wanita sebagai properti ini sudah menjadi bagian keseharian dari masyarakat Yunani kuno karena digaungkan oleh Homer sejak \pm 750 SM.

Kondisi sosial politik turut berpengaruh dalam pandangan masyarakat Yahudi pada masa itu. Setelah tanah Palestina dikuasai oleh Alexander Agung pada abat ke-4 SM, budaya Yunani mulai masuk dan menyebar di lingkungan orang Yahudi. Di mata orang Yahudi, khususnya mereka yang ingin mempertahankan identitas budaya Yahudi, budaya Yunani ini tampak atraktif tapi juga berbahaya. Sebagai dampaknya, para pemimpin agama Yahudi sengaja membuat berbagai peraturan yang membatasi perempuan untuk memastikan berlanjutnya garis keturunan Yahudi yang bercorak patriakhal. Mereka berharap agar melalui pembatasan yang ketat seperti ini, sebagian dari populasi, yaitu kaum perempuan, akan bisa 'diselamatkan' dari pengaruh budaya Yunani yang merusak; selain juga diharapkan akan mengurangi pengaruh perempuan-perempuan Yunani terhadap para laki-laki Yahudi (Swidler, 1976).

Selama Periode Intertestamental yang berlangsung selama sekitar 400 tahun antara masa terakhir penulisan Perjanjian Lama dan dimulainya peristiwa-peristiwa di Perjanjian Baru), ada dua kitab penting yang ditulis oleh para rabi Farisi yang membahas secara detil berbagai peraturan dan pandangan mengenai perempuan, yaitu Kitab Jubilee (ditulis antara 109 - 105 M) dan Kitab Perjanjian Dua Belas Patriakh (ditulis oleh seorang rabi Farisi antara tahun 109 - 106 SM).

Kitab Jubilee menekanan pentingnya menghindari perzinahan, terutama dengan perempuan asing. Sementara Kitab Perjanjian Dua Belas Patriakh menyatakan bahwa: a) Pada dasarnya setiap perempuan berpotensi membuat laki-laki yang baik jatuh ke dalam dosa dengan menggunakan tampilan luarnya yang atraktif (Reuben 5:1-2). Karena itu para laki-laki wajib melarang istri dan anak perempuan mereka menghiasi wajah dan rambut. Setiap perempuan yang menghias dirinya seperti itu dipastikan akan mengalami penghukuman kekal (Reuben 5:5). b) Perempuan lebih dikuasai oleh roh perzinahan dibandingkan laki-laki dan bahwa hati perempuan dipenuhi oleh skema untuk menghancurkan laki-laki (Reuben 5:3). Dengan demikian, laki-laki diperintahkan untuk tidak berinteraksi dengan perempuan karena perempuan adalah penghancur kekal laki-laki (Reuben 6:3-4) (Swidler, 1976). 
Sumber lain yang penting adalah tulisan Philo, sejarawan Yahudi yang tinggal di Alexandria - Mesir, dan hidup satu jaman dengan Kristus. Philo sangat dipengaruhi oleh filsafat Yunani, khususnya yang berasal dari filsuf Plato. Philo melihat perempuan sebagai makhluk yang inferior dibandingkan laki-laki; karena laki-laki memiliki superioritas dalam berpikir yang disebutnya sebagai pria (male) dibanding dengan sensasi persepsi yang didapati dari kelima indera yang disebut wanita (female). Karena itu di seluruh tulisannya, ia mengasosiasikan pikiran laki-laki yang aktif sebagai sesuatu yang baik dan superior, dan pikiran perempuan yang dipersepsikan sebagai yang pasif, inferior dan buruk (Stagg, 1978).

Dari contoh-contoh di atas bisa terlihat adanya jejak pengaruh pemikiran Yunani dalam pandangan terhadap perempuan, dimana perempuan dianggap properti yang harus dikendalikan karena sifat perempuan yang cenderung inferior, buruk dan berpotensi untuk merusak tatanan hidup masyarakat, khususnya untuk menghancurkan laki-laki.

\section{Sikap dan Pandangan Yesus Kristus terhadap Perempuan dari Interaksi-Nya dengan Perempuan yang Terdapat di Injil Sinoptik}

Keempat kitab Injil (Injil Sinoptik dan Injil Yohanes) merupakan sumber utama untuk memahami pandangan dan sikap Yesus Kristus terhadap perempuan. Dalam perjalanan kehidupan Yesus, para ahli Taurat dan orang Farisi menolak dan membenci Yesus karena mereka tidak mengerti misi dan sikap-sikapNya yang seringkali dianggap 'menyimpang' dari budaya Yahudi, termasuk dalam sikap-Nya terhadap perempuan. Bahkan murid-murid-Nya pun terkaget-kaget. Mereka tidak memahami bahwa Yesus melakukan transformasi terhadap adat dan budaya yang tidak sesuai dengan rancangan awal-Nya mengenai manusia, termasuk mengenai perempuan. Berikut ini adalah beberapa contoh dari sikap dan pandangan Yesus mengenai dan terhadap perempuan melalui berbagai interaksi-Nya dengan perempuan. Hanya diambil beberapa contoh saja akibat keterbatasan ruang.

\section{Perempuan yang Sakit Pendarahan (Markus 5:25-34, Matius 9:20-22, Lukas 8:43-48)}

Dalam budaya Yahudi, hal-hal yang berhubungan dengan darah, khususnya darah yang keluar dari tubuh perempuan, dianggap sebagai sesuatu yang najis (Imamat 15:25). Perempuan yang sedang menstruasi secara ritual dianggap kotor, dan setiap benda yang terkena noda dari menstruasi akan ikut dianggap najis (Richards \& Richards, 2003).

Peraturan ini dibuat oleh Allah sebagai bagian dari Hukum Taurat dengan tujuan untuk menyatakan standar kekudusan-Nya yang sangat ketat dan melampaui standar mana pun yang ditetapkan oleh ritus-ritus keagamaan. Jadi bukan diskriminasi gender yang ditekankan dalam peraturan ini, tetapi lebih kepada kekudusan Allah. Namun para rabi membuat interpretasi yang lebih jauh lagi dalam hal-hal yang berhubungan dengan menstruasi ini. Antara lain dengan menyatakan bahwa bersentuhan dengan wanita yang sedang menstruasi pun sudah merupakan kenajisan. Mereka menggunakan Imamat 15:31 sebagai teks yang membenarkan ajaran tersebut. Rabi Yoshayah misalnya. Ia menyatakan bahwa seorang suami dapat meninggal dunia jika bersentuhan dengan istrinya tidak hanya selama menstruasi, tapi bahkan sebelum dan sesudah masa menstruasi (Richards \& Richards, 2003).

Namun mujizat kesembuhan terjadi ketika perempuan yang pasti memahami kultur Yahudi pada masa itu, menyentuh-Nya dengan diam-diam. Yesus sengaja berhenti untuk bertanya siapa yang telah menyentuh jumbai jubah-Nya. Meskipun didesak oleh kebutuhan massa (Matius 9:36-38), Yesus sangat sensitif pada kebutuhan individual. Dari sini terlihat, Yesus memperlakukan perempuan itu sebagai seorang manusia yang dapat bertanggung-jawab untuk apa yang telah dilakukannya. 
Setelah perempuan itu mengakui perbuatannya, Yesus sama sekali tidak mengecamnya atau menganggapnya najis. Lukas 8:48 mencatat Ia bahkan menyebut perempuan itu sebagai thugatēr ( $\theta v \gamma \alpha ́ \tau \eta \rho)$ yang berarti 'anak perempuan'. Ia menghilangkan rasa rakut dan rasa bersalah dari perempuan itu dengan memberkatinya, yaitu dengan menyuruhnya pergi dalam damai.

Melalui peristiwa ini Yesus menunjukkan bahwa perempuan berharga sebagai manusia, bahkan jika ia dianggap najis oleh masyarakat akibat kondisi fisiknya. Ia mendobrak adat dengan menunjukkan kasihNya sebagai 'bapa' kepada perempuan itu di hadapan publik. Ia bahkan memberkati serta mengafirmasi tindakan perempuan itu, yang menurut ritual Yahudi pada masa itu sudah membuat-Nya terkontaminasi dengan kenajisan. Yesus bahkan memberi perempuan itu kesembuhan serta status baru sebagai anak-Nya.

\section{Perempuan Berdosa yang Mengurapi Kaki Yesus (Lukas 7:36-50)}

Di bagian pasal ini diceritakan tentang Yesus yang diundang untuk makan malam di rumah seorang Farisi yang bernama Simon. Di tengah-tengah perjamuan itu seorang perempuan yang dikenal sebagai pendosa memasuki ruangan. Perempuan ini berani masuk karena tradisi mengijinkan orang-orang miskin untuk masuk ke dalam perjamuan semacam itu untuk mendapatkan sisa-sisa makanan (Barker \& Kohlenberger III, 1997).

Walaupun begitu, perempuan ini khusus datang untuk menemui Yesus dan membasuh kaki-Nya dengan air mata dan meminyakinya dengan minyak wangi. Yesus tidak menolak apa yang dilakukan perempuan ini kepada-Nya.Tidak disebutkan dosa apa yang dilakukan oleh perempuan itu. Tapi dari cara Lukas menjelaskan perempuan itu sebagai "perempuan yang terkenal sebagai orang berdosa", yang menunjukkan suatu kombinasi antara 'berdosa' dan 'terkenal', maka kemungkinannya ia adalah seorang pelacur (Corley, 1993). Apalagi perempuan di masa itu hanya mempunyai sedikit pilihan. Jika ia seorang istri yang berzinah, ada kemungkinan ia sudah mati dirajam batu.

Dalam proses itu Simon langsung menghakimi Yesus di dalam hatinya. Bagi tradisi Yahudi saat itu, adalah najis jika seorang perempuan yang bukan anggota keluarga, apalagi perempuan pendosa, menyentuh seorang pria, terutama jika pria itu adalah seorang rabi dan bahkan nabi. Yesus yang mengetahui pikiran Simon, langsung menegurnya untuk tidak menghalangi perempuan itu dengan mengatakan "Simon, ada yang hendak Kukatakan kepada" (ayat 40). Tindakan Yesus dalam menegur Simon merupakan wujud dukungan pembebasan terkuat kepada perempuan yang pernah terjadi pada masa itu (Story, 2009).

Setelah menegur Simon, Yesus lalu menyampaikan sebuah perumpamaan tentang orang yang diampuni. Perumpamaan itu mengekspresikan pernyataan publik Yesus tentang pengampunan oleh iman bagi perempuan ini, seperti yang terdapat di ayat 47a: Sebab itu Aku berkata kepadamu: dosanya yang banyak itu telah diampuni, sebab ia telah banyak berbuat kasih.

Peristiwa ini menunjukkan otoritas Kristus terhadap tradisi dan hukum Taurat. Ia berotoritas untuk membatalkan semua tuntutan hukum Taurat terhadap perempuan ini dan memberinya pengakuan secara publik di depan Simon orang Farisi, anggota kelompok elit keagamaan yang dikenal sebagai 'penjaga dari Hukum Taurat'.

\section{Perempuan yang Menyebut Ibu-Nya Berbahagia (Lukas 11:27-28)}

Di dalam suatu kesempatan ketika Yesus sedang berbicara di hadapan orang banyak, seorang perempuan berkata bahwa ibu Yesus pastilah berbahagia karena telah mengandung dan menyusui-Nya. Ini 
adalah sebuah pernyataan yang tulus dari seorang perempuan yang hidup dalam budaya dimana tujuan utama dan keberhargaan dari perempuan adalah melahirkan anak.

Yesus tidak mengabaikan ungkapan hati perempuan ini, tapi Ia menjelaskan bahwa mereka yang berbahagia adalah yang mendengarkan dan menaati Firman Allah. Lewat jawaban-Nya ini Yesus mengarahkan fokus perempuan ini pada hal yang paling utama dalam hidup seseorang, termasuk hidup perempuan. Hal ini merupakan pandangan yang revolusioner di Palestina abad pertama, karena dalam Mishnah misalnya, orang Yahudi justru didorong untuk tidak mengajarkan Taurat yang merupakan Firman Allah kepada perempuan. Mishnah merupakan sumber tradisi lisan para rabi yang kompilasinya dimulai setelah penghancuran Yerusalem dan Bait Allah di tahun 70M dan yang terus berlangsung hingga sekitar tahun 200M. Mishnah sendiri berarti 'kedua' yang menunjukkannya sebagai 'hukum kedua' (Guignebert, 1959).

\section{Perempuan Samaria yang Ditemui Yesus di Pinggir Sumur (Yohanes 4:5-30 dan 39-42)}

Narasi ini berpusat pada perjumpaan Yesus dengan seorang perempuan Samaria di sumur Yakub di tengah hari yang terik. Fakta bahwa perempuan Samaria ini pergi ke sumur sendirian di tengah hari terik, menunjukkan bahwa kemungkinan besar ia telah diabaikan secara sosial oleh para perempuan lain (Malina \& Rohrbaugh, 1998). Namun yang luar biasa adalah realita bahwa Yesus, sebagai laki-laki dan rabi Yahudi, bercakap-cakap dengan perempuan Samaria, bahkan berdiskusi teologi dengannya. Misnah menganggap tidak pantas jika seorang laki-laki berdiskusi atau sekedar berbicara dengan seorang perempuan; karena hal itu akan merugikan laki-laki. Tak heran, baik perempuan Samaria itu sendiri (ayat 9) maupun murid-muridNya (ayat 27) heran dan terkejut dengan apa yang Yesus lakukan.

Yesus tidak cuma berbicara dengan perempuan Samaria itu, tapi Ia melanggar tradisi lainnya dengan meminta minum dari tempayan milik perempuan itu. Ini tidak sesuai dengan aturan orang Farisi yang menekankan kenajisan perempuan Samaria bagi orang Yahudi. Dengan Yesus meminta minum dari tempayannya, Ia memperlakukan perempuan ini sebagai bagian dari keluarga-Nya. Perempuan ini meresponi dengan memberi-Nya minum. Ini merupakan signal dimana transaksi interpersonal antara Yesus dan perempuan ini telah bergerak dari ranah publik ke ranah pribadi (Malina \& Rohrbaugh, 1998).

Yesus melanjutkan dialog ini dengan membahas kerinduan terdalam dari perempuan ini (ayat 13-15) melalui pembahasan tentang tentang air hidup. Ketika perempuan ini meminta air tersebut, Yesus menanyainya tentang suaminya. Perempuan ini menjawab dengan jujur, dan Yesus sampai dua kali memujinya untuk kejujurannya tersebut, sambil juga menyatakan kebenaran tentang diri perempuan ini (ayat 17 dan 18).

Ketika Yesus menyatakan diri-Nya sebagai Mesias, maka perempuan itu segera pergi menemui orang-orang di kotanya. Ini tindakan yang luar biasa karena sebelumnya ia berusaha menghindar dari interaksi dengan berangkat sendirian ke sumur di tengah hari. Kini ia kembali ke tengah masyarakat dan menyatakan dirinya apa adanya (ayat 29). Perempuan ini sebetulnya telah melanggar tradisi dengan berbicara secara mendalam dengan laki-laki asing. Tetapi rupanya bagi perempuan ini, pertemuan pribadi dengan Yesus telah mendobrak tradisi dan rasa malu, serta memberinya rasa berharga yang benar, yang didasarkan pada pengampunan dan pembaruan Allah yang penuh anugerah. Sebuah transformasi diri telah terjadi. Bagian ini diakhiri dengan transformasi dari orang-orang di kotanya.

Melalui peristiwa ini terlihat bahwa Yesus memahami kebutuhan dan kerinduan terdalam dari seorang perempuan. Ia mendobrak semua tradisi dan aturan yang dibuat manusia, yang menghalangi perempuan untuk bisa hidup sesuai dengan rancangan Allah bagi perempuan. Yesus tahu, ketika seorang 
perempuan telah mengalami transformasi akibat perjumpaan pribadi dengan-Nya, maka ia bisa jadi pribadi yang membawa banyak jiwa kepada-Nya.

Maria Magdalena (Matius 27:56, 61; 28:1-11, Markus 15:40, 47, 16:1-9, Lukas 8:2, 3, 24:1-12, Yohanes 19:25, 20:1, 2, 11-18)

Maria Magdalena sering disebut dalam berbagai peristiwa penting yang berhubungan dengan Yesus. Awalnya Yesus melepaskannya dari tujuh roh jahat yang menguasainya (Lukas 8:2). Hal ini bermakna penting bagi Maria, karena mereka yang dirasuk setan biasanya jadi orang buangan yang dianggap tidak pantas lagi hidup di tengah masyarakat (Karssen, 2000).

Ketika para penulis Injil mencatat tentang para murid yang menyaksikan penyaliban Yesus, satusatunya pria yang disebut adalah Yohanes. Tetapi kitab-kitab Injil justru mencatat tentang berberapa perempuan yang selalu ada di situ, antara lain Maria ibu Yesus dan Maria Magdalena. Meskipun berada di tengah kesedihan yang mendalam, keraguan dan ketakutan, para perempuan tetap setia bersama-Nya (Richards \& Richards, 2003).

Maria Magdalena juga ada di peristiwa penguburan Yesus (Mat 27:56) dan merupakan orang pertama yang menemukan bahwa kubur Yesus telah kosong (Mat 28:1). Bersama beberapa perempuan lain ia segera mencari Petrus dan menceritakan kabar ini, tapi Petrus tidak percaya (Lukas 24:1-12, Yohanes 20:1-3). Maria lalu kembali ke kubur dan menjadi orang pertama yang bertemu dengan Yesus serta mendengar suara-Nya paska kebangkitan-Nya (Markus 16:9).

Yohanes 20:16 bahkan mencatat, Yesus menyapa nama Maria secara pribadi: Kata Yesus kepadanya: “Maria!” Maria berpaling dan berkata pada-Nya dalam bahasa Ibrani: "Rabuni!”, artinya Guru. Dalam karyanya What's in a Name?, penulis Paul Tournier mengatakan bahwa nama panggilan menunjukkan sebuah nilai yang unik dan keberhargaan dari seorang manusia di hadapan Allah, yang muncul dari fakta bahwa Allah bicara kepadanya sebagai mitra dari sebuah dialog. Mitra yang merupakan refleksi dari gambar-Nya sendiri (Tournier, 1975). Melalui peristiwa ini Yesus menyatakan bahwa Maria, seorang perempuan, adalah manusia berharga untuk jadi mitra dialog dengan-Nya.

Budaya Yahudi tidak menerima kesaksian dari seorang perempuan. Buktinya para murid Yesus tidak percaya pada cerita Maria maupun para perempuan lain yang telah bertemu Yesus (Lukas 24:11, Markus 16:11). Bahkan Rasul Paulus tidak menyebutkan tentang pertemuan Maria atau para perempuan lain dengan Yesus dalam kesaksiannya tentang Yesus Kristus (1 Kor 15:5-7). Tapi kitab Markus (16:9) dan kitab Yohanes (30:14-18) dengan jelas mencatat bahwa Maria Magdalena adalah saksi pertama dari kebangkitan Yesus. Nama Maria Magdalena sendiri muncul hingga 14 kali dalam Injil (Karssen, 2000).

\section{Kesimpulan}

Berdasarkan komparasi antara dua perspektif utama yang telah dikaji di tulisan ini, yaitu yang berakar dari pemikiran Yunani kuno dengan perspektif Alkitabiah, terlihat jelas adanya perbedaan nyata di antara keduanya. Berbagai pandangan yang berakar dari pemikiran Yunani menunjukan bahwa perempuan dianggap sebagai properti yang lebih rendah dari laki-laki. Dengan demikian (khususnya di jaman Yunani kuno), perempuan perlu terus berdiam di rumah, jauh dari kehidupan publik. Selain itu, akibat natur perempuan yang cenderung dianggap buruk dan berpotensi merusak tatanan hidup masyarakat, khususnya laki-laki, maka perempuan perlu selalu diawasi dan dikendalikan. Fungsi utama dan keberhargaan utama 
perempuan adalah untuk melahirkan anak dan mengatur rumah. Kalau pun ada perempuan yang berkarya di sektor publik, maka biasanya berhubungan dengan area seksual.

Terdapat keserupaan nilai-nilai dalam masyarakat Romawi kuno yang secara aktif mengadopsi pemikiran dan kultur Yunani. Sementara itu, masyarakat Yahudi yang hidup di periode Intertestamental dan kemudian di jaman Perjanjian Baru dipengaruhi pula oleh pemikiran dan kultur Yunani ini. Perkembangan sosial politik berpengaruh terhadap munculnya kondisi ini. Demi melindungi kemurnian budaya Yahudi dari invasi budaya dan gaya hidup Romawi, para rabi Yahudi menciptakan berbagai tradisi dan hukum yang cenderung bersifat misognis (merendahkan dan membenci perempuan).Terdapat keserupaan dari jejak-jejak pemikiran Yunani mengenai perempuan dalam berbagai tradisi lisan maupun kitab-kitab hukum Yahudi yang lahir pada masa itu.

Sementara itu, Injil Sinoptik dan Injil Yohanes justru mencatat berbagai interaksi Yesus Kristus dengan perempuan yang berlawanan dengan tradisi dan hukum Yahudi pada masa itu. Berbagai interaksi itu mengingatkan kembali rancangan awal Allah mengenai manusia, termasuk mengenai perempuan. Seperti halnya laki-laki, Yesus melihat perempuan sebagai ciptaan yang "sungguh amat baik" dan berharga. Ia juga mati bagi dosa-dosa perempuan. Karena itu Ia menentang dan mematahkan berbagai pemikiran dan kultur yang membelenggu perempuan secara tidak tepat dan bahkan dengan sengaja memilih perempuan sebagai manusia pertama yang ditemui oleh-Nya paska kebangkitan-Nya.

\section{Referensi}

Aghababian, A. H. (2015). Ancient Greek Women and Warfare: Building a More Accurate Portrait of Ancient Women Through Literature. Inquiries Journal, 7(06).

Barker, K. L., \& Kohlenberger III, J. R. (Eds.). (1997). Zondervan NIV Vible Commentary Volume II: New Testament. Zondervan Publishing House.

Clark, G. (1981). Roman Women. Greece \& Rome, 28(02), 193-212.

Coggins, R. J. (1998). Sirach. Sheffield Academic Press.

Cook, J. (2008). Ben Sira's Perspective on Women-Jewish and/or Hellenistic? Journal for Semitics, 17(1), $1-18$.

Corley, K. E. (1993). Private Women Public Meals: Social Conflict in the Synoptic Tradition. Hendrickson Publishers.

Dupont, F. (1989). Daily Life in Ancient Rome. Blackwell Publishers.

Durant, W. (1939). The Life of Greece. Simon and Schuster.

Edwards, M. J. (2010). Early Christianity and Philosophy. In D. J. Bingham (Ed.), The Routledge Companion to Early Christian Thought.

Elm, S. (2012). Sons of Hellenism, Fathers of the Church: Emperor Julian, Gregory of Nazianzus, and the Vision of Rome. University of California Press.

Feldman, M. S., Skoldberg, K., Horner, D., \& Brown, R. N. (2004). Making Sense of Stories: A Rhetorical Approach to Narrative Analysis. Journal of Public Administration Research and Theory, 14(2), 147170.

Frost, F. J. (1971). Greek Society. D.C. Health and Company.
Glazebrook,
A. (2020).
Hetairai.
Oxford
Classical
Dictionary.

https://doi.org/https://doi.org/10.1093/acrefore/9780199381135.013.3080

Guignebert, C. (1959). The Jewish World in the Time of Jesus. University Books.

Haentjens, A. M. E. (2000). Reflections on Female Infanticide in the Greco-Roman World. L'Antiquite 
Classique, 69, 261-264.

Hunter, A., \& Brewer, J. (2015). Designing Multimethod Research. In S. Hesse-Biber \& R. B. Johnson (Eds.), The Oxford Handbook of Multimethod and Mixed Methods Research Inquiry (pp. 185-205). Oxford University Press.

Karamanous, M., Tsoucalas, G., Creatsas, G., \& Androutsos, G. (2013). The effect of Soranus of Ephesus (98-138) on the work of midwives. Women and Birth, 26, 226-228.

Karssen, G. (2000). Ia Dinamai Perempuan Jilid 2. Yayasan Kalam Hidup.

Lyons, D. (2003). Dangerous Gifts: Ideologies of Marriage and Exchange in Ancient Greece. Classical Antiquity, 22(1), 93-134.

Malina, B. J., \& Rohrbaugh, R. L. (1998). Social-Science Commentary on the Gospel of John. Fortress Press.

Mosier-Dubinsky, J. (2013). Women in Ancient Rome. JCCC Honors Journal, 4(2).

Nicolaides, A. (2016). Assessing Tertullian on the Status of Womenin the Third Century Church. Pharos Journal of Theology, 97.

Oost, S. I. (1978). Xenophon's Attitude Toward Women. The John Hopkins University Press, 71(4).

Pape, D. R. (1976). In Search of God's Ideal Woman. InterVarsity Press.

Richards, S. P., \& Richards, L. O. (2003). Women of the Bible. Nelson Reference \& Electronic.

Sacks, D. (2005). Encyclopedia of the Ancient Greek World, Revised Edition. Facts on File, Inc.

Seitkasimova, Z. A. (2019). Status of Women in Ancient Greece. Open Journal for Anthropological Studies, 3(2), 49-54.

Snyder, H. (2019). Literature review as a research methodology: An overview and guidelines. Journal of Business Research, 104, 333-339.

Stagg, E. \& F. (1978). Women in the World of Jesus. The Westminster Press.

Story, J. L. (2009). Female and Male in Four Annointing Stories. Priscilla Papers, 23(4), 16-23.

Swidler, L. (1976). Women in Judaism. The Scarecrow Press, Inc.

Todman, D. (2007). Childbirth in ancient Rome: From traditional folklore to obstetrics. Australian and New Zealand Journal of Obstetrics and Gynaecology, 47, 82-85.

Too, Y. L. (2001). Th Economies of Pedagogy: Xenophon's Wifely Didactics. The Cambridge Classical Journal, 47(January 2001), 65-80.

Tournier, P. (1975). What's in a Name? SCM Book Club. 